\title{
Influence of the Seasonal and Environmental Patterns and Host Reproduction on the Metazoan Parasites of Prochilodus lineatus
}

\author{
Maria de los Angeles Perez Lizama ${ }^{1}$, Ricardo Massato Takemoto ${ }^{1,2^{*}}$ and Gilberto Cezar \\ Pavanelli $^{1,2}$ \\ ${ }^{1}$ Pós-Graduação em Ecologia de Ambientes Aquáticos Continentais - PEA; Universidade Estadual de Maringá; \\ Bloco G-90; Av. Colombo, 5790; 87020-900; Maringá - PR - Brasil. ${ }^{2}$ Núcleo de Limnologia, Ictiologia e \\ Aqüicultura - Nupélia; Universidade Estadual de Maringá; Bloco G-90; Av. Colombo, 5790; \\ takemotorm@nupelia.uem.br; 87020-900; Maringá - PR - Brasil
}

\begin{abstract}
One hundred and forty-eight specimens of Prochilodus lineatus (Valenciennes, 1836) were collected on the Upper Paraná River floodplain, Brazil. Kritskyia boegeri presented significant differences in the abundance according to the host stage of gonadal maturity. Ergasilus sp. presented negative correlation between the GSR of the females and parasite abundance. K. boegeri presented negative correlation between the GSR of the males and abundance. Tereancistrum curimba and Saccocoelioides magnorchis occurred in higher abundance in the open lagoons. Rhinonastes pseudocapsaloideum and $\mathrm{S}$. nanii presented higher abundance in the channels and Tylodelphis sp. presented higher abundance in the closed lagoons and in the rivers. K. boegeri and Amplexibranchius sp. presented significant differences in their abundances between the months of the year. Saccocoelioides nanii presented higher abundances in February-March 2000. Only Tylodelphys sp. presented correlation between fluviometric level and abundance and $\mathrm{S}$. nanii presented significant correlation between water temperature and prevalence.
\end{abstract}

Key words: Prochilodus lineatus, parasite, Upper Paraná River floodplain, Brazil

\section{INTRODUCTION}

Prochilodus lineatus (Valenciennes, 1836) is a species that has always presented high biomass on the Upper Paraná River floodplain. After the closure of the reservoir of Sérgio Motta Hydroelectric Power Plant in Porto Primavera (São Paulo State) in November 1998, which caused the interruption of the critical phase of the floods on this floodplain (Veríssimo, 1999), the life cycle of the species underwent considerable change (Agostinho and Júlio Jr, 1999). This may have caused alterations in reproduction or the displacement of individuals in reproduction to other spawning grounds, with the consequent disappearance of young individuals from areas previously sampled. The impact that the species experienced has probably influenced the metazoan parasite community, modifying its structure. Few studies related to the parasite ecology of this species on the Upper Paraná River floodplain have been carried out (Ranzani-Paiva, et al., 2000). A recent work related to the parasite ecology of this species was developed by Martins et al. (2001). Therefore, the study of the seasonal dynamics of parasitism levels serves as a tool to understand

\footnotetext{
${ }^{*}$ Author for correspondence
} 
broad aspects that determine the population biology of the host-parasite system (Chubb, 1982). The objective of this work was the evaluation of the relationships between the host, Prochilodus lineatus, and its community of metazoan parasites regarding seasonal dynamics, as well as aspects referring to reproduction.

\section{MATERIALS AND METHODS}

One hundred and forty-eight specimens of Prochilodus lineatus were collected from February 2000 to May 2001 on the Upper Paraná River floodplain in the "Ilhas e Várzea do rio Paraná" Protected Area (Brazil) (Fig. 1). Fish captures were undertaken using gill nets. The total weight, standard length, gonad weight, sex and stage of gonadal maturity of each fish were recorded. The parasites were collected with the aid of a stereoscopic microscope (see Eiras et al., 2000).

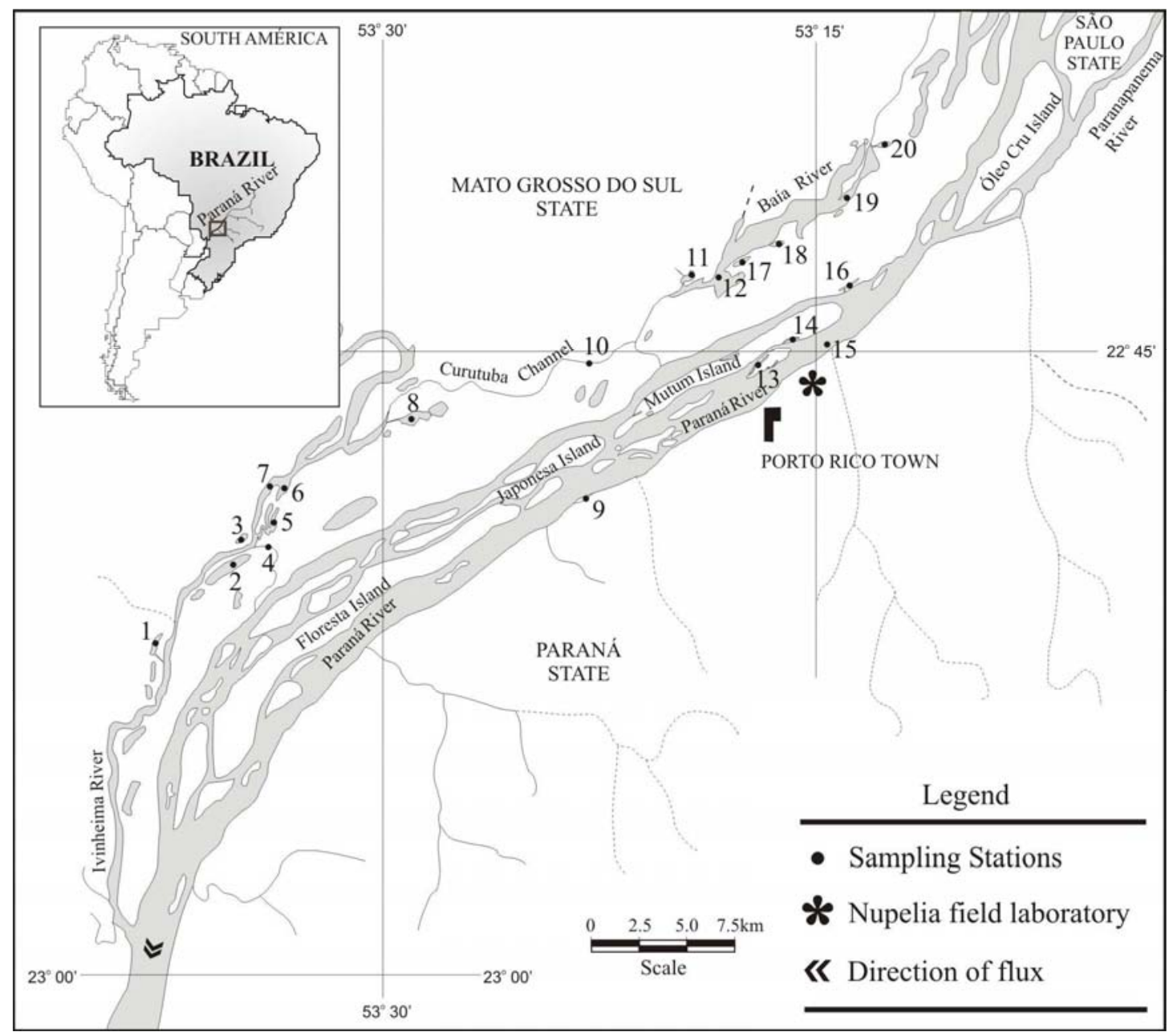

Figure 1 - Upper Paraná River floodplain. Sampling stations. 1. Peroba Lagoon, 2. Ventura Lagoon, 3. Zé do Paco Lagoon, 4. Ipoitã Channel, 5. Patos Lagoon, 6. Capivara Lagoon, 7. Ivinheima River, 8. Sumida Lagoon, 9. Cortado Channel, 10. Corutuba Channel, 11. Guaraná Lagoon, 12. Baia River, 13. Leopoldo Glades, 14. Pau Véio Glades, 15. Paraná River, 16. Garças Lagoon, 17. Fechada Lagoon, 18. Pousada das Garças Lagoon, 19. Baía Channel and 20. Onça Lagoon. 
The metazoan parasites were identified according to Thatcher (1978, 1979, 1991 and 1993), Thatcher and Boeger (1984a and b); Thatcher and Varella (1981), Moravec (1998), Takemoto et al. (2002) and Lizama et al. (2004). The environments were divided into Open Lagoons, which included the sites Onça Lagoon (Number of fishes collected $=5)$, Peroba Lagoon $(\mathrm{N}=3)$, Garças Lagoon $(\mathrm{N}=$ 19), Guaraná Lagoon $(\mathrm{N}=1)$, Patos Lagoon ( $\mathrm{N}=$ 4), Sumida Lagoon $(\mathrm{N}=1)$, Leopoldo Glade ( $\mathrm{N}=$ 13) and Pau Véio Glade ( $\mathrm{N}=5)$; Closed Lagoons, including Capivara Lagoon $(\mathrm{N}=4)$, Ventura Lagoon $(\mathrm{N}=4)$, Fechada Lagoon $(\mathrm{N}=8)$, Zé do Paco Lagoon $(\mathrm{N}=12)$ and Pousada das Garças Lagoon $(\mathrm{N}=10)$; Channels, including Ipoitã Channel $(\mathrm{N}=4)$, Baía Channel $(\mathrm{N}=3)$, Cortado Channel $(\mathrm{N}=9)$ and Corutuba Channel $(\mathrm{N}=2)$; and Rivers Ivinheima $(\mathrm{N}=5)$, Paraná $(\mathrm{N}=9)$ and Baía ( $\mathrm{N}=27)$.

The bimonthly frequency data of the stage of gonadal maturity, as well as the bimonthly mean of the gonadosomatic index, or GSR (expression between gonad weight and body weight of the fish), were used as a tool to determine the reproduction period of the "curimba". The monthly water temperature values were recorded. The monthly means of the fluviometric levels were provided by the Agência Nacional das Águas (ANA). Data analysis was carried out using Pearson's coefficient of correlation "r", with previous angular transformation of the prevalence values to determine possible correlation with water temperature and fluviometric level, in addition to Spearman's rank coefficient of correlation "rs", used to determine possible correlation between abundance of infection/infestation and the GSR, water temperature and fluviometric level. The Kruskall-Wallis " $\mathrm{H}$ " test was used to observe the differences in parasitism abundance between each period of gonadal maturity (immature, maturation, in reproduction, spent and at rest), according to Vazzoler (1996), in order to observe the differences between the diverse environments of the Upper Paraná River floodplain, as well as the differences in the months of the year (Zar, 1996).

The tests were applied to the species of parasites that presented prevalence higher than 10\% (Bush, et al., 1990). The statistical level of significance adopted was $\mathrm{p} \leq 0.05$.

The terminology related to parasite ecology was based on Bush et al. (1997).

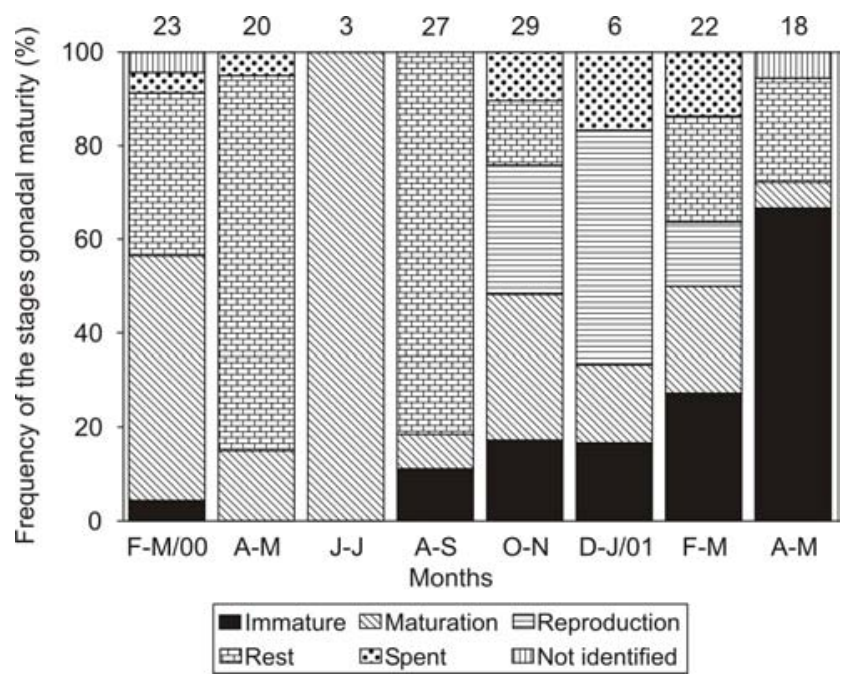

Figure 2 - Stages of gonadal maturity of the Prochilodus lineatus captured in the Upper Paraná River floodplain, from February 2000 to May 2001. (Numbers in the superior part of the graph refer to the number of analyzed fish).

\section{RESULTS}

\section{Reproduction}

Out of a total of 148 fishes examined, 120 specimens were parasitized by at least one species of parasite. Thirty-three species of metazoan parasites were recorded. A total of 2,660 parasites were collected and the majority of the specimens were digeneans. Only 11 species presented prevalence higher than $10 \%$. The study of the 
stage of gonadal maturity showed that the specimens of $P$. lineatus in reproduction occurred from October-November 2000 to February-March 2001, with the peak in December 2000-January 2001 (Fig. 2).

Kritskyia boegeri presented significant differences in the abundance values among the stages of host gonadal maturity (Table 1), with the lowest means in the immature stage (0.43) and the highest observed in the maturation and reproduction stages
(2.17 and 2.36, respectively). The highest values of the mean gonadosomatic relation (GSR) of the females occurred between October-November 2000 and February-March 2001, with the GSR peak in December 2000- January 2001. The males, despite presenting lower GSR values than the females, showed the same tendency. The period in which the highest GSR values occurred coincided with the rising water temperature values and the beginning of the high water period (Fig. 3).

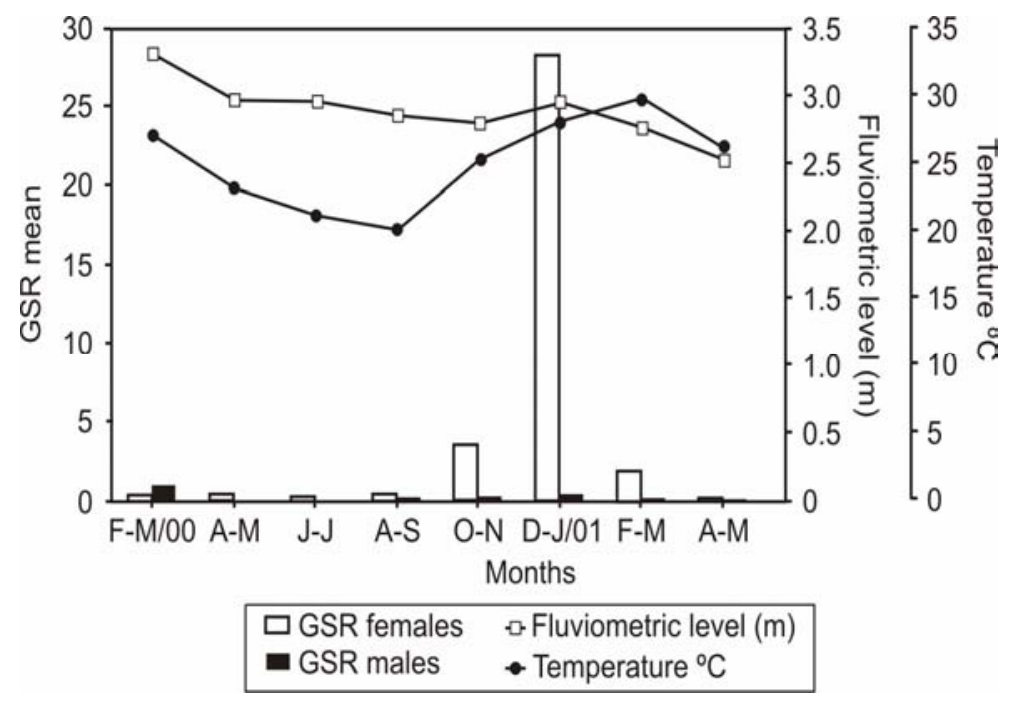

Figure 3 - Gonadosomatic Relation (GSR) of Prochilodus lineatus, temperature of the water $\left({ }^{\circ} \mathrm{C}\right)$ and fluviometric level $(\mathrm{m})$ in the Upper Paraná River floodplain, from February 2000 to May 2001.

Table 1 - Values of Kruskal-Wallis "H" test comparing the abundances of parasitism with the influence of stage of gonadal maturity of Prochilodus lineatus captured in the Upper Paraná River floodplain, from February 2000 to May 2001 ( $\mathrm{p}=$ level of significance)

\begin{tabular}{lcc}
\hline Parasite & H & p \\
\hline Monogenea & & \\
$\quad$ Rhinonastes pseudocapsaloideum & 5.937 & 0.2039 \\
Kritskyia boegeri & 10.210 & $0.0370^{*}$ \\
$\quad$ Tereancistrum curimba & 7.738 & 0.1017 \\
Digenea & & \\
$\quad$ Saccocoelioides magnorchis & 3.161 & 0.5313 \\
Saccocoelioides nanii & 5.462 & 0.2431 \\
Tylodelphis sp. (metacercariae) & 7.675 & 0.1042 \\
Acanthocephala & & \\
$\quad$ Neoechinorhynchus curemai & 4.038 & 0.4009 \\
Copepoda & & \\
$\quad$ Gamidactylus jaraquensis & 3.900 & 0.4197 \\
Gamispatulus sp. & 4.713 & 0.3180 \\
Amplexibranchius sp. & 5.450 & 0.2441 \\
Ergasilus sp. & 3.317 & 0.5062 \\
\hline
\end{tabular}

* Significant Values 
Table 2 - Values of Spearman's rank coefficient correlation "rs", correlating the GSR of the males and females with the abundance of parasitism for Prochilodus lineatus captured in the Upper Paraná River floodplain, from February 2000 to May 2001 ( $\mathrm{p}=$ significance level)

\begin{tabular}{|c|c|c|c|c|}
\hline \multirow{2}{*}{ Parasite } & \multicolumn{2}{|c|}{ Females } & \multicolumn{2}{|c|}{ Males } \\
\hline & $\mathbf{r s}$ & $\mathbf{p}$ & $\mathbf{r s}$ & $\mathbf{p}$ \\
\hline \multicolumn{5}{|l|}{ Monogenea } \\
\hline Rhinonastes pseudocapsaloideum & -0.0552 & 0.6450 & -0.2165 & 0.1123 \\
\hline Kritskyia boegeri & 0.0818 & 0.4944 & -0.3258 & $0.0152 *$ \\
\hline Tereancistrum curimba & 0.0067 & 0.9557 & -0.2624 & 0.0530 \\
\hline \multicolumn{5}{|l|}{ Digenea } \\
\hline Saccocoelioides magnorchis & 0.0155 & 0.8969 & -0.1453 & 0.2897 \\
\hline Saccocoelioides nanii & 0.1915 & 0.1071 & -0.1159 & 0.3993 \\
\hline Tylodelphis sp. (metacercariae) & 0.0347 & 0.7721 & 0.1345 & 0.3276 \\
\hline \multicolumn{5}{|l|}{ Acanthocephala } \\
\hline Neoechinorhynchus curemai & 0.2137 & 0.0715 & -0.1911 & 0.1623 \\
\hline \multicolumn{5}{|l|}{ Copepoda } \\
\hline Gamidactylus jaraquensis & 0.0306 & 0.7987 & -0.1992 & 0.1448 \\
\hline Gamispatulus sp. & -0.1665 & 0.1621 & -0.0947 & 0.4918 \\
\hline Amplexibranchius sp. & 0.0347 & 0.7721 & -0.0957 & 0.4871 \\
\hline Ergasilus sp. & -0.2754 & $0.0192 *$ & -0.2200 & 0.1065 \\
\hline
\end{tabular}

* Significant Values

The copepod Ergasilus sp. presented significant negative correlation between the GSR of the females and parasite abundance. In the male host, the monogenean Kritskyia boegeri presented significant negative correlation between the GSR and abundance. The monogenean Tereancistrum curimba also presented negative correlation; however, it was not very significant in the males (Table 2).

\section{Influence of the environment}

Several species of parasites presented significant differences among their abundances in the different environments of the Upper Paraná River floodplain. The monogenean T. curimba and the digenean $S$. magnorchis occurred in higher abundance in the hosts captured in the open lagoons (mean abundance $=1.31$ and 5.57, respectively) in relation to the other environments sampled. The monogenean $R$. pseudocapsaloideum and the digenean $S$. nanii presented higher abundance in the channels (mean abundance $=2.00$ and 28.75, respectively). The metacercaria Tylodelphys sp. presented higher abundance in the closed lagoons and in the rivers (mean abundance $=0.26$ and 0.25 , respectively) (Table 3).

\section{Seasonality}

Among the ectoparasites, the monogenean $K$. boegeri and the copepod Amplexibranchius sp. presented significant differences in their abundances between the months of the year (Table 4).

The most abundant months were: December 2000January 2001 for K. boegeri and June-July 2000 for Amplexibranchius sp. Among the endoparasites, Saccocoelioides nanii and Tylodelphis sp. presented significant differences between the months of the year and parasite abundance, with higher abundances in FebruaryMarch 2000 and December 2000- January 2001, respectively (Fig. 4 and Table 4 ).

Only the digenean Tylodelphis sp. presented significant positive correlation between fluviometric level and parasite abundance. No species presented significant correlation between fluviometric level and parasitism prevalence. Only $S$. nanii presented significant correlation between water temperature and parasitism prevalence (Tables 5 and 6). 
Table 3 - Values of Kruskall-Wallis "H" tests comparing the abundance of parasitism of Prochilodus lineatus captured in different environments (open ponds, closed ponds, channels and rivers) in the Upper Paraná River floodplain, from February 2000 to May 2001 ( $p=$ level of significance)

\begin{tabular}{lcc}
\hline \multicolumn{1}{c}{ Parasite } & H & p \\
\hline Monogenea & & $0.0209^{*}$ \\
Rhinonastes pseudocapsaloideum & 9.737 & 0.3593 \\
Kritskyia boegeri & 3.218 & $0.0363^{*}$ \\
Tereancistrum curimba & 8.526 & \\
Digenea & & $0.0169^{*}$ \\
Saccocoelioides magnorchis & 10.199 & $0.0354^{*}$ \\
Saccocoelioides nanii & 8.583 & $0.0229^{*}$ \\
Tylodelphis sp. (metacercariae) & 9.540 & 0.0518 \\
Acanthocephala & & \\
Neoechinorhynchus curemai & 7.737 & 0.9592 \\
Copepoda & & 0.0860 \\
Gamidactylus jaraquensis & 0.3042 & 0.5323 \\
Gamispatulus sp. & 6.594 & 0.7893 \\
Amplexibranchius sp. & 2.198 & \\
Ergasilus sp. & 1.049 & \\
\hline
\end{tabular}

* Significant Values

Table 4 - Values of Kruskall-Wallis "H" tests to verify the seasonality of the abundance of parasitism of Prochilodus lineatus captured in the Upper Paraná River floodplain, from February 2000 to May 2001 ( $p=$ level of significance)

\begin{tabular}{lcc}
\hline Parasite & H & p \\
\hline Monogenea & & \\
Rhinonastes pseudocapsaloideum & 13.623 & 0.0583 \\
Tereancistrum curimba & 13.109 & 0.0695 \\
Kritskyia boegeri & 22.567 & $0.0020^{*}$ \\
Digenea & & \\
Saccocoelioides magnorchis & 13.431 & 0.0623 \\
Saccocoelioides nanii & 14.254 & $0.0468^{*}$ \\
Tylodelphis sp. (metacercariae) & 21.522 & $0.0031^{*}$ \\
Acanthocephala & & \\
$\quad$ Neoechinorhynchus curemai & 5.324 & 0.6205 \\
Copepoda & & \\
Gamidactylus jaraquensis & 10.067 & 0.1848 \\
Gamispatulus sp. & 6.584 & 0.4734 \\
Amplexibranchius sp. & 14.095 & $0.0495^{*}$ \\
Ergasilus sp. & 13.924 & 0.0525 \\
\hline Significant Values & &
\end{tabular}

\footnotetext{
* Significant Values
} 

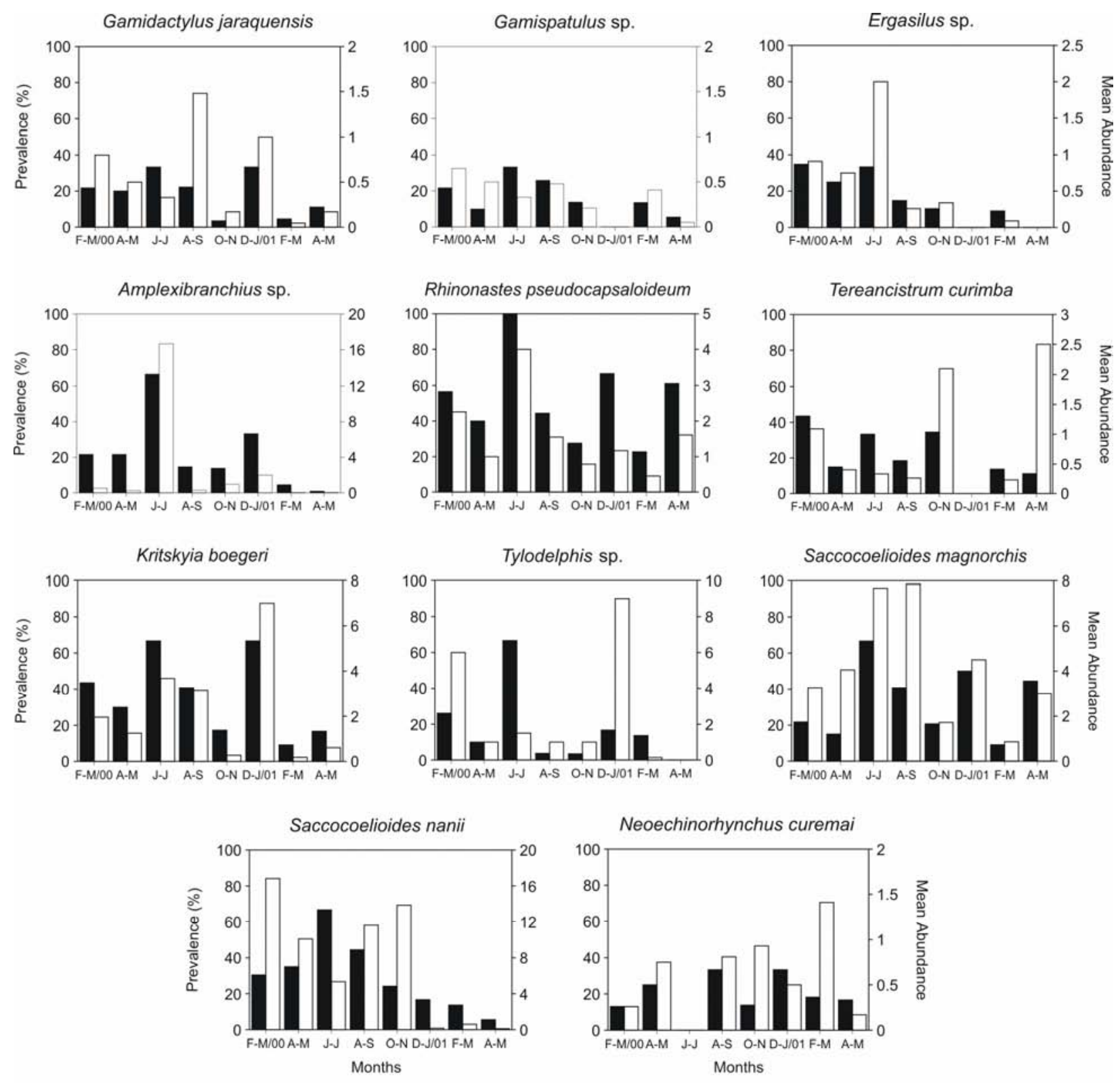

Prevalence (\%) $\square$ Mean Abundance

Figure 4 - Bimonthly values of de Mean Abundance and Prevalence of the metazoan parasites of the Prochilodus lineatus captured in the Upper Paraná River floodplain, from February 2000 to May 2001.

\section{DISCUSSION}

\section{Reproduction}

The results of the study of the stage of gonadal maturity and the mean GSR showed that the reproduction of Prochilodus lineatus on the Upper Paraná River floodplain (Brazil) was from October to March, with the peak in December. 
Table 5 - Values of Spearman's rank coefficient correlation "rs", correlating the fluviometric level and the abundance of parasitism and Pearson's coefficient correlation " $r$ " between the fluviometric level and prevalence of parasitism for Prochilodus lineatus captured in the Upper Paraná River floodplain, from February 2000 to May 2001 ( $\mathrm{p}=$ significance level $)$

\begin{tabular}{|c|c|c|c|c|}
\hline \multirow[t]{2}{*}{ Parasite } & \multicolumn{4}{|c|}{ Fluviometric level } \\
\hline & rs & $\mathbf{p}$ & $\mathbf{r}$ & $\mathbf{p}$ \\
\hline \multicolumn{5}{|l|}{ Monogenea } \\
\hline Rhinonastes pseudocapsaloideum & 0.4084 & 0.3268 & 0.1918 & 0.6490 \\
\hline Tereancistrum curimba & 0.1190 & 0.7930 & 0.3627 & 0.3772 \\
\hline Kritskyia boegeri & 0.5476 & 0.1710 & 0.5460 & 0.1615 \\
\hline \multicolumn{5}{|l|}{ Digenea } \\
\hline Saccocoelioides magnorchis & 0.4762 & 0.2431 & -0.0907 & 0.8308 \\
\hline Saccocoelioides nanii & 0.5476 & 0.1710 & 0.4970 & 0.2102 \\
\hline Tylodelphis sp. (metacercariae) & 0.7563 & $0.0368 *$ & 0.5921 & 0.1220 \\
\hline \multicolumn{5}{|l|}{ Acanthocephala } \\
\hline Neoechinorhynchus curemai & -0.3333 & 0.4279 & -0.1173 & 0.7821 \\
\hline \multicolumn{5}{|l|}{ Copepoda } \\
\hline Gamidactylus jaraquensis & 0.5749 & 0.1511 & 0.5021 & 0.2049 \\
\hline Gamispatulus sp. & 0.5952 & 0.1325 & 0.2694 & 0.5188 \\
\hline Amplexibranchius sp. & 0.4762 & 0.2431 & 0.4769 & 0.2322 \\
\hline Ergasilus sp. & 0.7186 & 0.0576 & 0.6860 & 0.0643 \\
\hline
\end{tabular}

* Significant Values

Table 6 - Values of Spearman's rank coefficient correlation "rs", correlating the temperature of the water and the abundance of parasitism and Pearson's coefficient correlation " $r$ " between the fluviometric level and prevalence of parasitism for Prochilodus lineatus captured in the Upper Paraná River floodplain, from February 2000 to May 2001 $\underline{(\mathrm{p}=\text { significance level })}$

\begin{tabular}{|c|c|c|c|c|}
\hline \multirow[t]{2}{*}{ Parasite } & \multicolumn{4}{|c|}{ Temperature of the water } \\
\hline & rs & $\mathbf{p}$ & $\mathbf{r}$ & $\mathbf{p}$ \\
\hline \multicolumn{5}{|l|}{ Monogenea } \\
\hline Rhinonastes pseudocapsaloideum & -0.3810 & 03599 & -0.4101 & 0.3129 \\
\hline Tereancistrum curimba & -0.2143 & 0.6199 & -0.3384 & 0.4123 \\
\hline Kritskyia boegeri & -0.3095 & 0.4618 & -0.3669 & 0.3713 \\
\hline \multicolumn{5}{|l|}{ Digenea } \\
\hline Saccocoelioides magnorchis & -0.6667 & 0.0831 & -0.4609 & 0.2504 \\
\hline Saccocoelioides nanii & -0.3333 & 0.4279 & -0.7756 & $0.0237 *$ \\
\hline Tylodelphis sp. (metacercariae) & 0.0244 & 0.9768 & -0.1793 & 0.6710 \\
\hline \multicolumn{5}{|l|}{ Acanthocephala } \\
\hline Neoechinorhynchus curemai & 0.2143 & 0.6191 & 0.2257 & 0.5910 \\
\hline \multicolumn{5}{|l|}{ Copepoda } \\
\hline Gamidactylus jaraquensis & -0.3713 & 0.3599 & -0.4056 & 0.3188 \\
\hline Gamispatulus sp. & -0.2381 & 0.5821 & -0.5862 & 0.1267 \\
\hline Amplexibranchius sp. & -0.2857 & 0.5008 & -0.4567 & 0.2554 \\
\hline Ergasilus sp. & -0.4791 & 0.2431 & -0.4534 & 0.2592 \\
\hline
\end{tabular}

* Significant Values

The results coincided with the findings of Vazzoler (1996) and Agostinho and Júlio Jr. (1999) on the Upper Paraná River floodplain and Terraes et al. (1999) in Argentina.

The frequency graph of the stage of gonadal maturity showed the presence of spent specimens starting in October. These results reinforced that the reproductive period of the species occurred between October and February. The presence of spent fish in February-March and April-May 2000 indicate was that in the previous year the reproductive period of the species altered by environmental changes on the floodplain.

The higher abundance of the monogenean $K$. boegeri coincided with the reproductive period of the host. This probably occurred because the 
period caused stress in the fish, leaving it more susceptible to parasitism. Zaman and Seng (1989), showed that the increase in the parasitism abundance of Clarias batrachus and $C$. macrocephalus coincided with the increase in fluviometric level and the gonadosomatic indices, which are indicators of the reproductive period of the host.

The study of the gonadosomatic index is used as a tool to increase the knowledge of the reproductive biology of a fish population. Gil de Pertierra and Ostrowski de Nuñez (1990) used this index in relation to the life cycle of a parasite, since it was intimately related to the life cycle of the host. Their results showed that the GSR peak, characteristic of the reproductive phase of the fish Rhamdia sapo, coincided with the maximum egg production of the cestode Proteocephalus jandia, whereas the output of gonadotropin by the fish was in synchrony with the peak of the ovoposition of the parasite. The occurrence of negative correlation between the GSR of the hosts and parasitism abundance, as observed for Ergasilus sp. in females and $K$. boegeri in males of $P$. lineatus, was also observed by Zaman and Seng (1989) for the parasites of $C$. batrachus and $C$. macrocephalus. Thomas (1964) and Pennicuick (1971a and b) suggested that the low infection by parasites during the spawning period, which coincided with the rainy period, occurred because of the presence of estrogen, a hormone that appeared in the blood of fish during maturation. After spawning, the hormone decreased, and the opposite happened.

\section{Influence of the environment}

According to Yañes and Canaris (1988), the reproductive migration pattern of a host can be a determining factor in the composition and structure of parasite communities. Youngs of the "curimba" (up to one year old) remain exclusively in the lagoons. From the first to the second year of life, the "curimba" makes short migrations to the streams and small rivers in the ebbing period in search of food and shelter. From the second year, $P$. lineatus begins to carry out long upward migrations to reproduce and downward migrations to feed and/or recuperate (Resende et al., 1996). Youngs of the "curimba" between 7-12 cm long, and adults between $40-50 \mathrm{~cm}$ long are found in lateral lagoons (shallow lagoons that fill in the flood period) and channels. During the floods, when the river reaches countless lagoons and islands of the floodplain, the fish migrate to the rivers or lagoons. At the end of the ebbing period, the shallow lagoons dry up, imprisoning large numbers of fish and leading to high mortality at these sites (Agostinho and Júlio Jr, 1999).

Ectoparasites are considered typical of lentic environments because the free-swimming larval forms easily find their host in these environments. Tereancistrum curimba and Rhinonastes pseudocapsaloideum are examples. These species present eggs without filaments, typical of habitats with little water flow. However, they were found in higher abundance in semi-lotic and lotic (channels and rivers) environments. This may have occurred due to the migration pattern of the host. The short and long migrations that this species carries out over its lifetime permit the fish to exploit diverse environments, increasing the possibility of infection/infestation by diverse species of parasites. In this way, the "curimba" is able to become bearer and disseminator of parasites in the several environments of the Upper Paraná River floodplain.

Regarding endoparasites, their presence in higher abundance in the open lagoons and channels may be evidence of the presence of intermediate invertebrate hosts that serve as food for the "curimba", in addition to the detritus and sediment that compose its diet (Hahn et al., 1997). Takeda et al. (2000) found that in the diverse subsystems of the Upper Paraná River floodplain, many lagoons and glades were interconnected to the main channel, influenced by the fluviometric fluctuation of the river, which often turns the lentic environment into a lotic one, favoring the establishment of these species of intermediate hosts and consequently the parasites in these environments. This interconnection of subsystems also explained the dissemination of ectoparasites.

\section{Seasonality}

Not all parasite species of $P$. lineatus of the Upper Paraná River floodplain presented the same seasonal pattern. Of the species that presented significant seasonal variation, Amplexibranchius sp. presented the highest abundance in June-July, before the hosts left the lagoons for the river to form schools and later began reproductive migration (Agostinho and Júlio Jr., 1999). On the other hand, Kritskyia boegeri was more abundant in December 2000-January 2001, during reproductive period of the host. 
Many abiotic factors affect the abundance and prevalence of parasites. Among these, temperature is one of the most important in the parasite-hostenvironment relationship (Kennedy, 1982). Williams and Jones (1994) observed that the development and reproduction of fish was directly related to temperature. Vazzoler et al. (1997) suggested that there was a synchrony between the abiotic factors, which functioned as triggers, causing the maturation of the gametes and consequently the reproduction of the species of fish. Among these triggers, temperature, fluviometric level and photoperiod are the most important. Thomas (1964) concluded that the spawning of Salmo truta was directly related to the flood period and the hormonal levels of the fish, and the parasitism levels were related to both. Works similar to these were carried out by Pennicuick (1971a and b) and Nie and Kennedy (1991).

Some studies showed that for most of the species of fish, the rise in temperature increased the intensity of infection by the parasites (Hanzelová and Zitnan, 1982, 1983; Gelnar, 1987). However, the results obtained in this work showed that the water temperature on the floodplain presented negative correlation only with the parasitism prevalence for $S$. nanii. Gil de Pertierra and Ostrowski de Nuñez (1995) suggested that each species of parasite used a range of specific ideal temperature, which triggered physiological development processes of the parasite. These patterns, in addition to temperature, are influenced by factors connected to the life cycle of the parasite (availability of cercariae, metacercariae and final host), host biology (diet during its development, and during the seasons and migrations) and other possible final hosts. Bauer (1959) showed that factors such as age, physiological condition, host migration and season were very important as regards parasitism levels. The results obtained in this work suggested that fluviometric level directly influenced the $P$. lineatus population and indirectly influenced the community of metazoan parasites, as in the case of Tylodelphis sp., which presented positive correlation regarding abundance and fluviometric level. These results were in agreement with those observed by Stromberg and Crites (1974), who suggested that more than temperature, fluviometric level influenced the population of copepods, intermediate hosts of the nematodes, object of that study. Zaman and Seng (1989) also suggested that the extra peaks in abundance could be explained by the fact that in the dry period, the intermediate hosts were more congregated, thus increasing the chances of infection.

According to Veríssimo (1999), the intensity and duration of the flood period greatly influenced the reproductive success of the species of fish. In years in which the flood period was intense and lasting, the offspring of migratory species, as in the case of the "curimba", reached the lagoons in search of food and shelter, occurring in large numbers of specimens. In years in which the flood period was short, migratory species presented lower densities. With the closure of Sérgio Motta Reservoir in 1998, the floods were interrupted, resulting in migratory species (e.g. P. lineatus) recruitment failures (Júlio, Jr. et al., 2000). These failures caused reduction in the population existing in the region, and/or influenced the exit of part of the "curimba" population to other environments, which could have interfered with the metazoan parasite community of the Upper Paraná River floodplain.

\section{ACKNOWLEDGMENTS}

We would like to thank Nupélia (Center for Research in Limnology, Ichthyology and Aquaculture, Universidade Estadual de Maringá UEM) for the use of its facilities in carrying out this research and the Graduate Course in the Ecology of Continental Aquatic Environments (UEM) for its support during every stage of this work. We also thank Dr. José L. Luque (UFRRJ Universidade Federal Rural do Rio de Janeiro) and Dr. Harumi Irene Suzuki (UEM) for help with the critical reading of the manuscript. R.M.Takemoto and G.C. Pavanelli was supported by a Research fellowship from $\mathrm{CNPq}$ (Conselho Nacional de Desenvolvimento Científico e Tecnológico).

\section{RESUMO}

Cento e quarenta e oito espécimes de Prochilodus lineatus (Valenciennes, 1836) foram coletados na planície de inundação do Alto rio de Paraná, Brasil. Kritskyia boegeri apresentou diferenças significativas na abundância de acordo com os estágios de maturação de gonadal do hospedeiro. Ergasilus $s p$ apresentou correlação negativa entre o RGS das fêmeas e a abundância parasitária. $K$. 
boegeri apresentou correlação negativa entre o RGS dos machos e a abundância. Tereancistrum curimba e Saccocoelioides magnorchis ocorreram em abundância mais alta nas lagoas abertas. Rhinonastes pseudocapsaloideum e $S$. nanii apresentaram abundância mais alta nos canais e Tylodelphis sp. apresentou abundância mais alta nas lagoas fechadas. $K$. boegeri e Amplexibranchius sp. apresentaram diferenças significativas em suas abundâncias durante os meses do ano. Saccocoelioides nanii apresentou abundâncias mais altas nos meses de fevereiromarço de 2000. Somente Tylodelphis sp. apresentou correlação entre nível fluviométrico e abundância e $S$. nanii apresentou correlação significativa entre a temperatura da água $\mathrm{e}$ prevalência de parasitismo.

\section{REFERENCES}

Agostinho, A. A. and Júlio Jr, H. F. (1999), Peixes da Bacia do Alto Rio Paraná. In: Lowe-McConnel, R. H. (Ed.). Estudos de comunidades de peixes tropicais São Paulo: EDUSP. pp. 374-399.

Bauer, O. N. (1959), The influence of environmental factors on reproduction of fish parasites. Ivopr. Ekol. (Izdat. Kiev. Univ.), 3, 320-335.

Bush, A. O.; Aho, J. M. and Kennedy, C. R. (1990), Ecological versus phylogenetics determinants of helminth parasite community richness. Evol. Ecol., 4, 1-20.

Bush, A. O.; Lafferty, K. D.; Lotz, J. M. and Shostak, A. W. (1997), Parasitology meets ecology on its own terms: Margolis et al. revisited. J. Parasitol., 83, 575-583.

Chubb, J. C. (1982), Seasonal occurrence of helminths in freshwater fishes. Part IV. Adult Cestoda, Nematoda and Acanthocephala. Adv. Parasit., 20, 1-292.

Eiras, J. C.; Takemoto, R. M. and Pavanelli, G. C. (C2000), Métodos de estudio y técnicas laboratoriales en parasitología de peces. Zaragoza: Editorial Acribia.

Gelnar, M. (1987), Experimental verification of the effect of water temperature on micropopulation growth of Gyrodactylus katharineri Malmberg, 1964 (Monogenea) parasitizing carp fry (Cyprinus carpio L.). Folia Parasitol., 34, 19-23.

Gil de Pertierra, A. A. and Ostrowski de Nuñez, M. (1990), Seasonal dynamics and maturation of the cestode Proteocephalus jandia (Woodland, 1933) in the catfish (Rhamdia sapo). Acta Parasitol. Pol., 35, 305-313.
Gil de Pertierra, A. A. and Ostrowski de Nuñez, M. (1995), Ocurrencia estacional de Acantosthomum gnerii Szidat, 1954 (Acanthostomidae, Acanthostominae) y de dos espécies de Derogenidae, Halipeginae, parásitos del bagre sapo Rhamdia sapo Valenciennes, 1840 (Pisces, Pimelodidae) en Argentina. Rev. Brasil. Biol., 55, 305-314.

Hahn, N. S.; Andrian, I. F.; Fugi, R. and Almeida, V. L. (1997), Ecologia Trófica. In: Vazzoler, A. E. A. M.; Agostinho, A. A. and Hahn, N. S. (Eds.). A planície de inundação do alto rio Paraná: aspectos físicos, biológicos e socioeconômicos. Maringá; EDUEM. pp. 209-228.

Hanzelová, V. and Zitnan, R. (1982), The seasonal dynamics of the invasion cycle of Gyrodactylus katharineri Malmberg, 1964 (Monogenea). Helminthologia, 19, 257-265.

Hanzelová, V. and Zitnan, R. (1983), The seasonal dynamics of the invasion of Dactylogyrus vastator Nybelin, 1924 (Monogenea) in the carp fry. Helminthologia., 20, 137-150.

Júlio Jr., H. F.; Petry, A. C.; Russo, M. R. and Gomes, L. C. (2000), Ictiofauna. In: UEM. Nupelia/ PELD. Relatório técnico 2000. Disponível em: <http//www.peld.uem.br/Relatorio/index.htm>.

Acesso em: 17 jun. 2003. pp. 31-147.

Kennedy, C. R. (1982), Biotic factors. In: Mettrick, D. F. and Desser,S. S. (Eds.). Parasites - their world and ours. Proceedings of the fifth International Congress of Parasitology. Toronto, Canada, 1982. Elsevier Biomedical Press. Amsterdam: The Netherlands. pp. 293-302.

Lizama, M. A. P.; Takemoto, R. M. and Pavanelli, G. C. (2004), New species of Tereancistrum Kritsky, Thatcher and Kayton, 1980 (Monogenea: Dactylogyridae: Ancyrocephalinae) from the gills of Prochilodus lineatus (Osteichthyes: Prochilodontidae) from the upper Paraná River floodplain, Brazil. Syst. Parasitol., 57, 45-49.

Martins, M. L.; Moraes, F. R.; Fujimoto, R. Y.; Onaka, E. M. and Quintana, C. I. F. (2001), Prevalence and 1973 histopathology of Neoechinorhynchus curemai Noronha, (Acantocephala: Neoechinorhynchidae) in Prochilodus lineatus Valenciennes, 1836 from Volta Grande Reservoir, MG, Brazil. Brazil. J. Biol., 61, 517-522.

Moravec, F. (1998), Nematodes of freshwater fishes of the Neotropical region. Czech Republic: Academia Praha.

Nie, P. and Kennedy, C. R. (1991), Ocurrence and seasonal dynamics of Pseudodactylogyrus anguillae (Yin and Sproston) (Monogenea) in eel, Anguilla anguilla (L.), in England. J. Fish Biol., 39, 897-900.

Pennicuick, L. (1971a), Seasonal variation in the parasite infection in a population of three-spined Sticklebacks G. aculeatus. Parasitology, 63, 373-388. 
Pennicuick, L. (1971b), Diferences in the parasite infections in the three-spined sticklebacks (Gasterosteus aculeatus L. ) of different sex, age and size. Parasitology, 63, 407-418.

Ranzani-Paiva, M. J. T.; Silva-Souza, A. T.; Pavanelli, G. C. and Takemoto, R. M. (2000), Hematological characteristics and relative condition factor $(\mathrm{Kn})$ associated with parasitism in Schizodon borelli (Osteichthyes, Anostomidae) and Prochilodus lineatus (Osteichthyes, Prochilodontidae) from Paraná River, Porto Rico region, Paraná, Brazil. Acta Scientiarum, 22, 515-521.

Resende, E. K.; Catella, A. C.; Nascimento, F. L.; Palmeira, S. S.; Pereira, R. A. C.; Lima, M. S. and Almeida, V. L. L. (1996), Biologia do curimbatá (Prochilodus lineatus), pintado (Pseudoplatystoma corruscans) e cachara (Pseudoplatystoma fasciatum) na bacia hidrográfica do Rio Miranda, Pantanal do Mato Grosso do Sul, Brasil. EMBRAPA-CPAP, Corumbá, MS: (EMBRAPA-CPAP. Boletim de Pesquisa, 02).

Stromberg, P. C. and Crites, J. L. (1974), The life cycle and development of Camallanus oxycephalus Ward and Magath, 1916 (Nematoda: Camallanidae). $J$. Parasit., 60, 117-124.

Takeda, A. M.; Higuti, J.; Pereira, S. R. da S.; Monkolski; A. M., Bubena, M. R.; Furita, D. S.; Moretto, Y.; Amaro, C. S.; Bibian, J. P. R.; Fujihara, R. T. and Braga, C. P. (2000), Zoobentos. In: UEM. Nupelia/PELD. Relatório técnico 2000. Disp. em: < http//www.peld.uem.br/Relatorio/index.htm>. Acesso em: 17 jun. 2003. pp. 123-129.

Takemoto, R. M.; Lizama, M. A. P. and Pavanelli, G. C. (2002), A new species of Kritskyia (Dactylogyridae, Ancyrocephalinae) parasite of urinary bladder of Prochilodus lineatus (Prochilodontidae, Characiformes) from the floodplain of the high Paraná river, Brazil. Mem. Inst. Oswaldo Cruz, 97, 313-315.

Terraes, J. C.; Bechara, J. A.; Roux, J. P.; Flores Quintana, C.; Domitrovic, H. A. and Sánchez, S. (1999), Ciclos reproductivos del sábalo (Prochilodus lineratus) y de sardina de río (Hemiodus orthonops) (Pisces, Characiformes) en el río Paraná águas abajo de la represa de Yacyretá, Argentina. Rev. Ictiol., 7, 91-104.

Thatcher, V. E. (1978), Quatro espécies novas da família Haploporidae (Trematoda: Digenea) de peixes de água doce da Colômbia, com uma revisão do gênero Saccocoelioides Szidat, 1954. Acta Amazônica, 8, 477-487.

Thatcher, V. E. (1979), Paramphistomidae (Trematoda: Digenea) de peixes de água doce: dois novos gêneros da Colômbia e uma redescrição de Dadaytrema oxycephala (Diesing, 1836) Travassos, 1934, da Amazônia. Acta Amazônica, 9, 203-208.

Thatcher, V. E. (1991), Amazon fish parasites. Amazoniana, 11, 263-571.
Thatcher, V. E. (1993), Trematodeos neotropicais. INPA, Manaus.

Thatcher, V. E. and Varella, A. B. (1981), Duas novas espécies de Megacoelium Szidat, 1954 Trematoda: Haploporidae), parasitas estomacais de peixes da Amazônia Brasileira, com uma redefinição do gênero. Acta Amazônica, 11, 285-289.

Thatcher, V. E. and Boeger, W. (1984a), The parasitic crustaceans of fishes from the Brazilian Amazon. 13. Gamidactylus jaraquensis gen. et sp. nov. (Copepoda: Poecilostomatoida: Vaigamidae) from the nasal fossae of Semaprochilodus insignis (Schomburgk). Amazoniana, 8, 421-426.

Thatcher, V. E. and Boeger, W. (1984b), The parasitic crustaceans of fishes from the Brazilian Amazon. 15. Gamispatulus schizodontis gen. et sp. nov. (Copepoda: Poecilostomatoida: Vaigamidae) from the nasal fossae of Schizodon fasciatus Agassiz. Amazoniana, 9, 119-126.

Thomas, J. D. A. (1964), Comparasion between the helminth burdens of male and female brown trout, Salmo trutta (L.) from a natural population in River Teify, West Wales. Parasitology, 54, 263-272.

Vazzoler, A. E. M. (1996), Biologia da reprodução de peixes teleósteos: teoria e prática. Maringá: EDUEM; São Paulo: SBI.

Vazzoler, A. E. A. M.; Suzuki, H. I.; Marques, E. E. and Lizama, M. A. P. (1997), Primeira maturação gonadal, períodos e áreas de reprodução. In: Vazzoler, A. E. A. M.; Agostinho, A. A. and Hahn, N. S. (Eds.). A planície de inundação do alto rio Paraná: aspectos físicos, biológicos e socioeconômicos. Maringá: EDUEM. pp. 249-265.

Verissimo, S. (1999), Influência do regime hidrológico sobre a ictiocenose de três lagoas da planície aluvial do alto Rio Paraná. Ph. D. Thesis, Universidade Federal de São Carlos, São Carlos.

Williams, H. and Jones, A. (1994), Parasitic worms of fish. London: Taylor and Francis.

Yañes, D. M. and Canaris, A. C. (1988), Metazoan parasite community composition and structure of migrating Wilson's Phalarope, Steganopus tricolor Viellot, 1819 (Aves), from El Passo country, Texas. J. Parasitol, 74, 754-462.

Zaman, Z. and Seng, L. T., (1989), The seasonal abundance of the parasite in Clarias batrachus and $C$. macrocephalus from two areas (Kedah and Perak) of Malaysia and its relationship to the maturity of the hosts. Bangladesh J. Zool., 17, 47-55.

Zar, J. H. (1996), Biostatistical Analysis. $3^{\text {rd }}$ ed. New Jersey: Upper Saddle River.

Received: September 09, 2004; Revised: May 05, 2005; Accepted: February 06, 2006. 